\title{
ПЕЧАТНАЯ ЭЛЕКТРОХИМИЧЕСКАЯ ЯЧЕЙКА СО СМЕННЫМ РЕАКТОРОМ ДЛЯ ПРОТОЧНОГО АНАЛИЗА МЕТАБОЛИТОВ
}

\author{
Стойков Д.И., Евтюгин Г.А. \\ Казанский (Приволжский) федеральный университет, Казань, Россия \\ Der.Knight@yandex.ru
}

DOI: 10.26902/ASFE-11_132

В рамках развития персонифицированной медицины ведутся исследования по разработке и внедрению в клиническую практику простых носимых анализаторов, предназначенных для своевременного получения информации о состоянии больного, включая концентрации метаболитов, остаточных количеств лекарственных препаратов и биомаркеров заболеваний.

Нами разработана компактная ячейка для электрохимических измерений, которая могла бы быть использована в подобных анализаторах, состоящая из полимерного проточного корпуса и сменного реактора для иммобилизации биологических компонентов. Компоненты ячейки выполнены из полимолочной кислоты с помощью 3D-печати. Благодаря высокой скорости изготовления, воспроизводимости параметров получаемых изделий, гибкости предлагаемого дизайна ячейки, адаптируемого под конкретный аналит, и невысокой себестоимости изготовления использование 3D-печати является перспективным способом создания тест-систем. Полилактид был выбран для изготовления ячейки в силу его совместимости с основными протоколами иммобилизации биомолекул, легкости биоразложения после окончания эксплуатации изделия и возможности использования на современных 3D-принтерах. В данной конструкции ячейки диск из полилактида использовали в качестве универсального сменного реактора для иммобилизации ферментов путем карбодиимидной сшивки. Электрохимические измерения в проточной ячейке проводили с помощью планарного электрода, изготавливаемого с помощью трафаретной печати на поликарбонатной основе, поток жидкости через ячейку осуществляли с помощью шприцевого насоса ALS. Электрод модифицировали путем электрополимеризации тионина и метиленового синего из общего раствора мономеров в режиме многократного циклирования потенциала. Для увеличения регистрируемых токов электрод предварительно модифицировали углеродной чернью и медиатором электронного переноса пиллар[5]ареном (П5А). УЧ и П5А наносили капельно из суспензии в пропиленкарбонате, обеспечившем более высокие воспроизводимость электрохимических характеристик модифицированного электрода и регистрируемые токи красителей по сравнению с другими пленкообразователями. Охарактеризованы кинетические параметры переноса электрона.

Проточная ячейка была использована для иммобилизации ферментов - оксидоредуктаз с последующим определением их субстратов: уриказы (мочевая кислота), тирозиназы (допамин, тирозин) и др. Раствор аналита пропускали в непрерывном режиме через рабочую камеру со сменным реактором и регистрировали медиаторный ток восстановления продукта, образующегося в ферментативной реакции, как меры содержания субстрата в образце. Условия измерения сигнала были первоначально установлены по стандартным растворам продуктов ферментативной реакции. Разработанная проточная ячейка продемонстрировала чувствительность к метаболитам - субстратам организма на микро- и субмикромолярном уровне концентраций (для мочевой кислоты предел обнаружения составил $1 \cdot 10^{-8} \mathrm{M}$ ) как в буферных растворах, так и в модельных образцах искусственной урины, что позволяет использовать данную систему для определения медицински значимых метаболитов в биологических образцах. 